\title{
Comparison of single event multilevel surgery and multiple surgical events in the lower extremities of children with spastic cerebral palsy
}

\author{
Spastik serebral palsili çocukların alt ekstremitelerinde tek aşamada \\ çok seviyeli cerrahi ve çok aşamalı cerrahinin karşılaştırılması
}

\author{
Ahmet Aslan, $\mathrm{MD}^{1}\left(\mathbb{D}\right.$, Sabri Kerem Diril, $\mathrm{MD}^{2}$ (D), Demir Demirci, $\mathrm{MD}^{3} \mathbb{D}$, Hüseyin Yorgancıgil, $\mathrm{MD}^{4}(\mathbb{D}$ \\ 'Department of Orthopedics and Traumatology, Alanya Alaaddin Keykubat University, Faculty of Medicine, Antalya, Turkey \\ ${ }^{2}$ Department of Orthopedics and Traumatology, University of Health Sciences, İstanbul Kanuni Sultan Süleyman SUAM, Istanbul, Turkey \\ ${ }^{3}$ Department of Orthopedics and Traumatology, Isparta City Hospital, Isparta, Turkey \\ ${ }^{4}$ Department of Orthopedics and Traumatology, Private Isparta Hospital, Isparta, Turkey
}

\begin{abstract}
Objectives: This study aims to compare patients treated with single event multilevel surgery (SEMS) and multiple surgical events (MSE) for disorders of the lower extremities due to cerebral palsy $(\mathrm{CP})$.

Patients and methods: The study included 130 patients (74 males, 56 females; mean age $7.7 \pm 4$ years; range, 4 to 13 years) who were retrospectively staged preoperatively and at the final follow-up with the Gross Motor Function Classification System (GMFCS). The patients were divided into two groups as group 1 (MSE) and group 2 (SEMS). Gross Motor Function Measure-88 (GMFM-88) was used as evaluation criteria and visual analog scale was used to measure family satisfaction.
\end{abstract}

Results: In the final follow-up, group 2 had better GMFM$88 \mathrm{D}$ and $\mathrm{E}$ scores $(\mathrm{p}=0.037$ and $\mathrm{p}=0.045$, respectively). Similarly, family satisfaction was better in group $2(\mathrm{p}=0.047)$. There was a difference between preoperative and final followup GMFCS stages (I, II, III) of all patients (21/53/56 and 53/49/28; respectively, $\mathrm{p}<0.001$ ). A total of 3.8 (range, 2-7) operations were performed per child.

Conclusion: In this study, SEMS contributed significantly to movement, posture and independence of children with CP compared to MSE. Single event multilevel surgery also increased family satisfaction.

Keywords: Cerebral palsy, single event multilevel surgery, spasticity.

\section{öz}

Amaç: Bu çalışmada serebral palsi (SP)'ye bağlı alt ekstremite rahatsızlıkları için tek aşamada çok seviyeli cerrahi (TAÇSC) ve çok aşamalı cerrahi (ÇAC) ile tedavi edilen hastalar karşılaştırıldı.

Hastalar ve yöntemler: Çalışmaya geriye dönük olarak ameliyat öncesinde ve son takipte Kaba Motor Fonksiyon Sinıflandırma Sistemi (KMFSS) ile evrelendirilen 130 hasta (74 erkek, $56 \mathrm{kız}$; ort. yaş $7.7 \pm 4$ yıl; dağılım, 4-13 yıl) dahil edildi. Hastalar grup 1 (ÇAC) ve grup 2 (TAÇSC) olmak üzere iki gruba ayrıldı. Değerlendirme ölçütü olarak Kaba Motor Fonksiyon Ölçütü-88 (KMFÖ-88) ve aile memnuniyetini ölçmek için Görsel Analog Ölçeği kullanıld1.

Bulgular: Son takipte grup 2'nin KMFÖ-88 D ve E skorları daha iyiydi (sırasıyla, $\mathrm{p}=0.037$ ve $\mathrm{p}=0.045$ ). Benzer şekilde, aile memnuniyeti grup 2'de daha iyiydi ( $\mathrm{p}=0.047$ ). Tüm hastaların ameliyat öncesi ve son takip KMFSS evreleri (I, II, III) arasinda farklılık vard 1 (sirasiyla, 21/53/56 ve 53/49/28; p<0.001). Çocuk başına toplam 3.8 (dağılım, 2-7) ameliyat yapıld1.

Sonuç: Bu çalışmada, TAÇSC SP'li çocukların hareket, postür ve bağımsızlığg açısından ÇAC'ye göre anlamlı katkı sağladı. Tek aşamada çok seviyeli cerrahi aile memnuniyetini de artırdı.

Anahtar sözcükler: Serebral palsi, tek aşamada çok seviyeli cerrahi, spastisite. 
Children with spastic-type cerebral palsy (CP) have the risk of joint contractures and bone deformities over time. The aim of orthopedic treatment is to correct the contractures and deformities, increase the patient's function and abilities, and ensure independence of the individual. ${ }^{[1-5]}$

Multi-level surgical approach in a single stage -single event multilevel surgery (SEMS)- is the currently preferred orthopedic surgical management to improve gait and function in children with $\mathrm{CP}^{[4-7]}$ However, some authors suggest multiple surgical events (MSE), emphasizing the risks of simultaneous surgical procedures in dysfunctional muscle groups. ${ }^{[8,9]}$ Besides, evaluation examinations related with the satisfaction of parents are not common in studies comparing the two methods. ${ }^{[10]}$ There is also limited data comparing the clinical parameters after SEMS and MSE styles of treatment. In this study, we aimed to compare patients treated with SEMS and MSE for disorders of the lower extremities due to $\mathrm{CP}$.

\section{PATIENTS AND METHODS}

This study was conducted at Süleyman Demirel University Medicine Faculty Hospital, Kastamonu and Afyonkarahisar State Hospital between November 2003 and August 2013. In the study, records of children with spastic $\mathrm{CP}$, who underwent soft tissue surgical treatment due to their contractures/deformities, were analyzed retrospectively. Demographic information, diagnosis, Gross Motor Function Classification System (GMFCS) stage, additional diseases, orthopedic surgical procedure and rehabilitation information were recorded.

Of these, 142 patients who met the inclusion criteria and had regular controls were called for the last follow-up. A total of 130 patients (74 males, 56 females; mean age $7.7 \pm 4$ years; range, 4 to 13 years) returned the call and they were divided into two groups as group 1 (MSE) and group 2 (SEMS) for evaluation.

The criteria for inclusion consisted of a diagnosis of spastic diplegic CP, level I-III according to the GMFCS, ability to walk with or without an auxiliary device, one-sided or bilateral surgery performed for at least two contractures, patients receiving a similar rehabilitation program, patients who did not undergo previous orthopedic surgery in another hospital, patients without bone surgery, patients without diagnosis of a neoplasm, and patients who did not undergo botulinum toxin injections within six months prior to surgery.
The study protocol was approved by the Süleyman Demirel University Medicine Faculty Hospital, Clinical Research Ethics Committee (No: 2013/2760). A written informed consent was obtained from parents of each patient. The study was conducted in accordance with the principles of the Declaration of Helsinki.

Preoperative decision for surgery, operative procedures and postoperative care were made regarding the relevant literature. ${ }^{[1,2,4-8,11-14]}$ The patients were observed while sitting, standing and walking. We evaluated walking disorders such as toe-walking, scissoring, jumping, crouch knee gait, and stiff knee gait. Clinical examination findings and special clinical tests revealed contracted joints and related spastic muscles. All patients were operated under general anesthesia; uni- or bilateral, single-level or multilevel soft tissue surgeries were performed by two orthopedic surgeons with sufficient experience in the diagnosis and treatment of CP. In this retrospective study, the experience of surgeons was the determining factor in the choice of approach. Because of our lack of experience, we applied the MSE approach in the initial cases. In the later cases, we preferred SEMS.

Choice of the surgical procedure according to the pathology were as follows: hip flexion contracture; psoas or iliopsoas release, hip adduction contracture; adductor tenotomy, knee flexion contracture; fractional hamstring lengthening, knee extension contracture; rectus plasty or transfer, ankle deformity; the Achilles tendon z-plasty or vulpius procedure, the varus deformity of the foot; posterior tibial tendon lengthening, or anterior tendon split transfer, valgus deformity of the foot; peroneal tendon lengthening. Following hip flexor release, the patient was laid in prone position part time for the first few weeks, and following adductor tenotomy of the hips; abduction orthosis/pillow was applied at night for four-six weeks. After hamstring release, rectus transfer or plasty, long leg bivalve plaster cast was applied for four weeks. After Achilles, tibialis posterior and peroneal tendon lengthening, vulpius procedure and anterior tibial tendon split transfer bivalve and short leg plaster casts were applied for four weeks. During the rehabilitation period, knee-ankle-foot orthosis (KAFO) or ankle-foot orthosis (AFO) orthosis was used after cast removal.

Two to three days after the operation, the patient was able to adapt to passive isometric exercises in the cast. After removal of the cast, range of motion and isometric exercises were started. Patients were encouraged to stand and walk, giving as much weight as they could tolerate. When the muscle strength 
reached a sufficient level, three to six months of intensive rehabilitation program was applied in order to strengthen the elongated muscles, to abandon the old habits of the patients and to prevent pathological posture. Parents were informed by physiotherapists for home rehabilitation program. Patients were referred to the Spastic Children Education and Rehabilitation Center for occupational and recreational therapy.

Patients were staged according to GMFCS at the preoperative and final follow-up. ${ }^{[15,16]}$ GMFCS is a guide in the treatment planning of the patient with $\mathrm{CP}$ and in selecting the appropriate treatment method. It is a valid and reliable method for determining the expectation level within objective criteria, choosing an appropriate orthopedic approach and predicting motor function.

At the final follow-up, functional evaluation of the patients was performed with GMFM-88. ${ }^{[14]}$ Several studies have shown that GMFM- 88 is a useful and reliable measure in evaluating $\mathrm{CP}$ treatment results. ${ }^{[12,17]}$ It consists of five subdivisions and a total of 88 activities. Scoring is based on a four-point
(0-3 points) Likert scale. The score taken in each section is divided into the maximum points that can be taken in that section, and then multiplied by 100 and the percentage score obtained for that section is found. The level of performing gross motor skills of the patient with $\mathrm{CP}$ increases as the score increases. ${ }^{[12]}$ The GMFM-88 standing (D) and walking, running and stair climbing (E) sections are widely used in the clinical setting to evaluate gait. ${ }^{[17]}$ In our study, we also used the D and E subdivisions of GMFM- 88 .

Satisfaction of the patients was evaluated using a 10-point visual analog scale (VAS). ${ }^{[10]}$ According to this scale, 0 means completely unsatisfied and 10 is rated as totally satisfied.

Sample size is advised to be 50 or 60 to assess walking improvement initiatives in $\mathrm{CP}^{[18]}$ In our study, we formed the groups considering these numbers.

\section{Statistical analysis}

All analyses were conducted using the IBM SPSS version 22.0 (IBM Corp., Armonk, NY. USA). Continuous variables were expressed as

TABLE I

Comparison of demographic features and clinical outcomes according to groups

\begin{tabular}{|c|c|c|c|c|c|c|}
\hline \multirow[t]{2}{*}{ Parameter } & \multicolumn{2}{|c|}{ Group-1 MSE (n=72) } & \multicolumn{2}{|c|}{ Group-2 SEMS $(n=58)$} & \multirow{2}{*}{$\begin{array}{c}\text { Total }(\mathrm{n}=130) \\
\mathrm{n}\end{array}$} & \multirow[b]{2}{*}{$p$} \\
\hline & $\mathrm{n}$ & Mean $\pm S D$ & $\mathrm{n}$ & Mean $\pm S D$ & & \\
\hline Gender & & & & & & $0.726^{*}$ \\
\hline Female & 32 & & 24 & & 56 & \\
\hline Male & 40 & & 34 & & 74 & \\
\hline Comorbidity & & & & & & $0.065^{\star}$ \\
\hline+ & 21 & & 26 & & 47 & \\
\hline- & 51 & & 32 & & 83 & \\
\hline Side & & & & & & $0.768^{*}$ \\
\hline Left & 27 & & 21 & & 48 & \\
\hline Right & 23 & & 16 & & 39 & \\
\hline Bilateral & 22 & & 21 & & 43 & \\
\hline GMFCS level preoperative & & & & & & $0.236^{*}$ \\
\hline I & 11 & & 10 & & 21 & \\
\hline II & 34 & & 19 & & 53 & \\
\hline III & 27 & & 29 & & 56 & \\
\hline GMFCS level postoperative & & & & & & $0.418^{\star}$ \\
\hline 1 & 30 & & 23 & & 53 & \\
\hline II & 24 & & 25 & & 49 & \\
\hline III & 18 & & 10 & & 28 & \\
\hline Mean Age (ears) & & $7.5 \pm 2.5$ & & $7.9 \pm 2.8$ & & $0.384^{* *}$ \\
\hline Mean fallow-up (months) & & $63.4 \pm 33.7$ & & $59.4 \pm 34.5$ & & $0.508^{* *}$ \\
\hline GMFM-88 D section postoperative & & $67.7 \pm 12.3$ & & $71.9 \pm 10.4$ & & $0.037^{* *}$ \\
\hline GMFM-88 E section postoperative & & $51.7 \pm 12.7$ & & $56.2 \pm 12.8$ & & $0.045^{\star *}$ \\
\hline Satisfaction VAS postoperative & & $6.4 \pm 1.6$ & & $6.9 \pm 1.5$ & & $0.047^{* *}$ \\
\hline
\end{tabular}

MSE: Multiple surgical events; SEMS: Single event multilevel surgery; GMFCS: Gross Motor Function Classification System; GMFM-88: Gross Motor Function Measure-88; VAS: Visual analog scale; ${ }^{*}$ Pearson chi-square; ${ }^{* *}$ Independent t-test. 
TABLE II

Details of surgical procedures

\begin{tabular}{lc}
\hline Orthopedic soft tissue surgery & Number of operations \\
\hline Achilles tendon lengthening & 137 \\
Hamstring lengthening & 129 \\
Adductor tenotomy & 98 \\
Vulpius procedure & 47 \\
Iliopsoas tenotomy & 39 \\
Psoas lengthening & 18 \\
Rectus transfer & 9 \\
Split transfer of tibialis anterior & 6 \\
Posterior tibialis lengthening & 5 \\
Rectus release & 4 \\
Peroneal tendon lengthening & 3 \\
\hline
\end{tabular}

Totally 3.8 operations per child (range, 2-7) for all patients.

the mean \pm standard deviation. The normality of distributions was evaluated with a one-sample Kolmogorov-Smirnov test. Comparison of categorical and continuous variables between two groups was performed using the chi square test and independentsamples t-test, respectively. A paired t-test was used to compare the preoperative and final control stages for all patients. A two-tailed $\mathrm{p}<0.05$ was considered statistically significant.

\section{RESULTS}

The demographic and clinical characteristics of patients in the two groups are shown in Table I. No significant differences were observed in age, gender, side, GMFCS stage or additional disease between two groups ( $\mathrm{p}>0.05)$. Of the cases, $48(36.9 \%)$ were rightsided, $39(30 \%)$ were left-sided and $43(33.1 \%)$ were bilateral. Various additional diseases were present in $47(36.2 \%)$. The mean follow-up period was $61.59 \pm 33.96$ months (range, 24-126 months).

In the final follow-up, GMFM-88 D and E scores of group 2 was better and there was a statistically significant difference between the groups $(p=0.037$ and $\mathrm{p}=0.045$, respectively). Similarly, parental satisfaction was better in group 2 with a statistically significant difference between the groups $(p=0.047)$. There was a statistically significant difference between preoperative and final control GMFCS stages (I, II, III) of all patients (21/53/56 and 53/49/28; $\mathrm{p}<0.001$, paired t-test, respectively). Patients in group 1 underwent one or more surgeries at least two different times (range, 2-4). Patients in group 2 underwent at least two (range, 2-5) surgeries in the same session. There were 3.8 operations per child (range, 2-7) for all patients. The performed
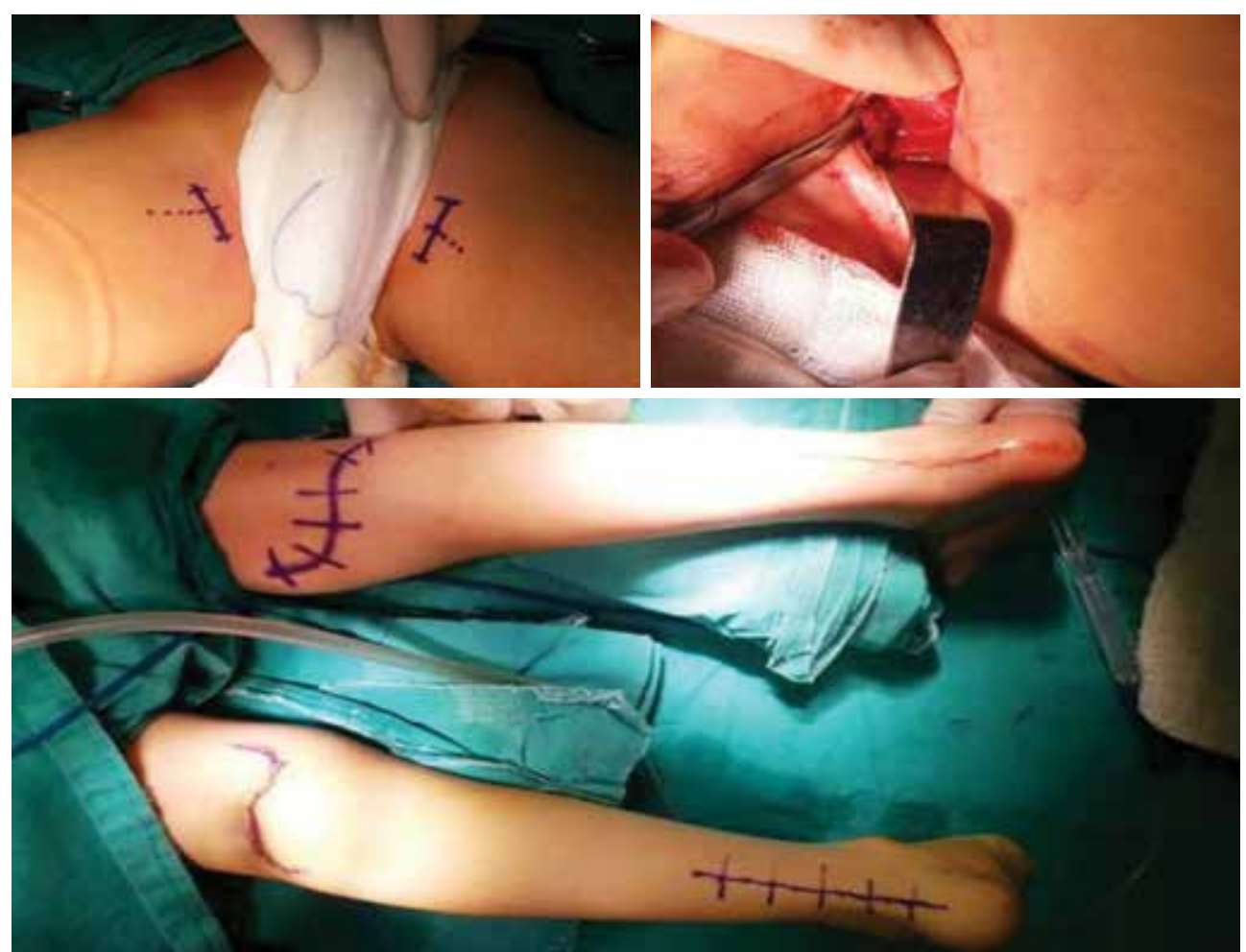

Figure 1. Intraoperative photographs, single event multilevel surgery for bilateral spastic diplegic cerebral palsy. 

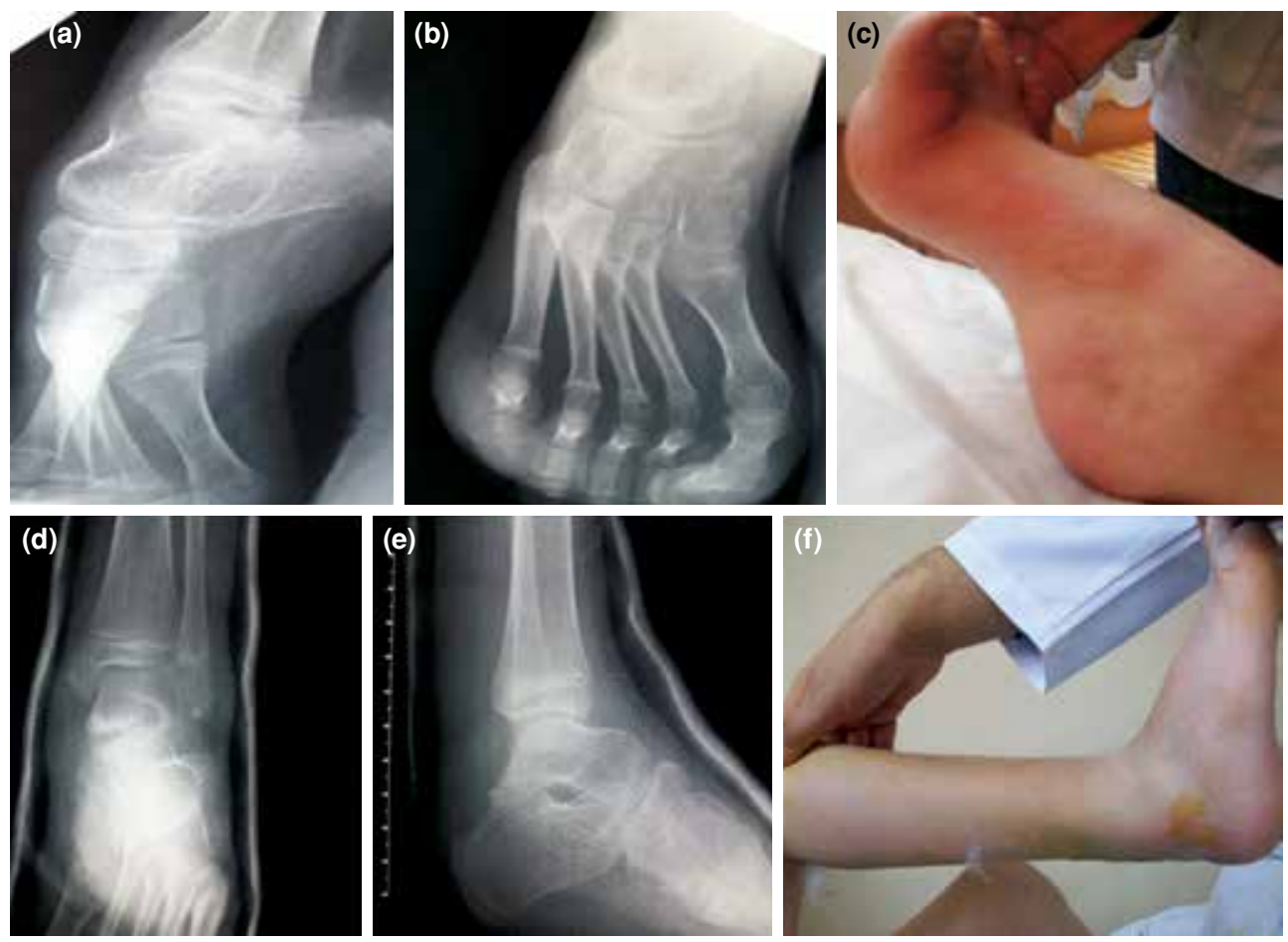

Figure 2. Eight-year-old girl with diplegic cerebral palsy. (a-c) Pre- and (d-f) postoperative pictures of patients who underwent achilloplasty.

operations and the total number of operations are presented in Table II. Examples of our cases are presented in Figures 1 and 2. No infection or any other complication was observed in any patient.

\section{DISCUSSION}

The major results of this study were as follows: (i) at the last follow-up, the GMFM-88 D and E scores were significantly greater in group 2 than those in group 1; (ii) VAS scores were significantly greater in group 2 than those in group 1; (iii) the improvement in GMFCS between the groups in terms of preoperative and final follow-up evaluation was better in group 2; (iv) there were 3.8 operations per child (range, 2-7) for all patients.

In this study, we found better outcomes in group 2 in terms of GMFM-88 D and E scores. Notably, the five-item GMFM-88 is an important assessment tool for CP treatment results. Furthermore, the GMFM$88 \mathrm{D}$ is used for standing, while the GMFM-88 $E$ is used for motion functions. ${ }^{[14,15,17]}$ Thomason et al. ${ }^{[19]}$ reported randomized controlled trials of spastic children indicating that SEMS improved gait 12 months after surgery. Moreover, Abel et al. ${ }^{[20]}$ reported a significant increase in the standing, walking and jumping activities according to GMFM-88 with SEMS. Similarly, Koca et al. ${ }^{[4]}$ reported a significant improvement in SEMS and GMFM-88 scores, while Oeffinger et al. ${ }^{[17]}$ reported a significant positive association between section $\mathrm{E}$ scores of GMFM-88 and GMFCS level. The GMFM- 88 section E score is an important predictor of the GMFCS level, so the higher scores in the GMFM- 88 section $E$ vehicles have reported lower levels in GMFCS. This finding may be related to the possibility that single-session surgery allows continuous rehabilitation without any cessation for further surgical procedures and there is no need for repeated operations.

In this study, we achieved better results with SEMS in terms of VAS scores. Significant reduction in VAS in SEMS group may be due to releasing of contracture and spasm. The decrease in pain level may also affect the quality of life of the individual. However, parents' satisfaction or related issues have not been adequately studied in the literature. In such a study evaluating parents' satisfaction, Lee et al. ${ }^{[2]}$ followed-up for an average of 2.2 years 61 patients with an average age of 10.2 years during surgery. They also determined parents' satisfaction with the surgical outcome by using the 10-point VAS and found the mean of 6.8. The authors reported that significant improvements in scores in the sport/physical activity subscale and improvement in preoperative GMFCS levels affect parent satisfaction. In another study, ${ }^{[10]}$ 
they analyzed parental satisfaction after SEMS in ambulatory children with $\mathrm{CP}$ using the VAS scale: (i) the mean number of surgical procedures per patient was 5.4; (ii) the mean follow-up period after surgery was 6.6 years; (iii) the mean postoperative satisfaction was 7.9. They stated that true satisfaction could be lower than reported in the study due to the inability to reach unsatisfied parents.

Gross Motor Function Classification System is used to show results of treatment with $\mathrm{CP}$ and expressed to describe locomotor function parameters. In ambulatory patients (GMFCS levels I, II and III), SEMS is widely accepted as the gold standard for improving gait. ${ }^{[9,22]}$ It has been reported that surgical treatment is planned more accurately and the results are more successful by performing static and dynamic examination together ${ }^{[4,14]} \mathrm{A}$ number of other studies in the orthopedic literature have also accepted a significant positive change in the level of GMFCS after SEMS. Godwin et al. ${ }^{[23]}$ demonstrated improvements in GMFCS levels after SEMS and this effect may depend on the level. Zorer et al. $^{[5]}$ reported that 23 children who underwent muscle-tendon SEMS had at least one improvement in all subjects at the GMFCS level. In this study, we also detected better results for GMFCS in group 2 in terms of improvement from the preoperative period to the final follow-up.

In our study, an average of 3.8 surgical procedures were performed per child for all patients. Various studies have given different average operation numbers per child. Wood et al. ${ }^{[2]}$ performed a total of 58 surgical procedures including soft tissue and ostoetomies and 5.8 surgical procedures per patient. Also, in their cases, the mean age during surgery was nine years and 10 months (range, 6-14 years). Godwin et al. ${ }^{[23]}$ operated 84 children with a mean age of six years with an average of 5.45 operations per child. They also stated that there was no relationship between the number of surgical procedures performed and the change in GMFCS level. Harwey et al. ${ }^{[25]}$ performed an average of eight surgical procedures per child in children aged 10 years. They also stated that the GMFCS level significantly changed after SEMS particularly in high-function children. Gupta et al. ${ }^{[13]}$ performed a total of 153 surgical procedures and a mean of 4.5 procedures per child in 34 patients with a mean age of 9.53 years. The deformities were completely corrected after the surgery in all of the children in their series. This difference may be due to the fact that the average age in the literature mentioned above is higher than our study.

Some limitations of this study should be considered. This is a retrospective study. In addition, the preoperative GMFM- 88 values of the patients were not measured. Moreover, some patients were lost to final follow-up.

In conclusion, our SEMS interventions showed a significant contribution to mobility, posture and independence of children with CP compared to MSE in this retrospective study. At the same time, the satisfaction of the parents was also higher in group 2 . We believe that further prospective and randomized studies should be performed to achieve healthier data on this subject.

\section{Declaration of conflicting interests}

The authors declared no conflicts of interest with respect to the authorship and/or publication of this article.

\section{Funding}

The authors received no financial support for the research and/or authorship of this article.

\section{REFERENCES}

1. Çullu E. Serebral Palsi. In: Emre Çullu, editör, Çocuk Ortopedisi. İstanbul: Bayçınar Tıbbi Yayıncılık; 2012. s. 365-85.

2. Berker AN, Yalçin MS. Cerebral palsy: orthopedic aspects and rehabilitation. Pediatr Clin North Am 2008;55:1209-25.

3. Oto M, Sarıkaya İA, Erdal OA, Şeker A. Surgical reconstruction of hip subluxation and dislocation in children with cerebral palsy. Eklem Hastalik Cerrahisi 2018;29:8-12.

4. Koca K, Yıldız C, Yurttaş Y, Balaban B, Hazneci B, Bilgiç S, Başbozkurt M. Outcomes of multilevel orthopedic surgery in children with cerebral palsy. Eklem Hastalik Cerrahisi 2011;22:69-74.

5. Zorer G, Doğrul C, Albayrak M, Bagatur AE. The results of single-stage multilevel muscle-tendon surgery in the lower extremities of patients with spastic cerebral palsy. Acta Orthop Traumatol Turc 2004;38:317-25.

6. Şaylı U, Avcı S, Şaylı A. Sımultaneous multipl operations fort he lower extremity contractures of spastic cerebral palsied patients. Eklem Hastalik Cerrahisi 1999;10:160-4.

7. Thomason P, Selber P, Graham HK. Single Event Multilevel Surgery in children with bilateral spastic cerebral palsy: a 5 year prospective cohort study. Gait Posture 2013;37:23-8.

8. Sussman MD, Aiona MD. Treatment of spastic diplegia in patients with cerebral palsy. J Pediatr Orthop B 2004;13:1-12.

9. Mahmudov V, Gunay H, Kucuk L, Coskunol E, Calis Atamaz F. Comparison of single event vs multiple event soft tissue surgeries in the lower extremities with cerebral palsy. J Orthop 2015;12:171-5.

10. Lee SH, Chung CY, Park MS, Choi IH, Cho TJ, Yoo WJ, et al. Parental satisfaction after single-event multilevel surgery in ambulatory children with cerebral palsy. J Pediatr Orthop 2009;29:398-401.

11. Kay RM. Lower limb surgery in Childern with Serebral Palsy. In Skaggs DL, Kocher MS, editors. Master Techniques in Orthopaedic Surgery: Pediatrics 2nd ed. Philadelphia: Lippincott Williams \& Wilkins 2015. p. 149-92. 
12. Chang $\mathrm{CH}$, Chen YY, Yeh KK, Chen CL. Gross motor function change after multilevel soft tissue release in children with cerebral palsy. Biomed J 2017;40:163-168.

13. Gupta A, Srivastava A, Taly AB, Murali T. Single-stage multilevel soft-tissue surgery in the lower limbs with spastic cerebral palsy: Experience from a rehabilitation unit. Indian J Orthop 2008;42:448-53.

14. Schwartz MH, Viehweger E, Stout J, Novacheck TF, Gage JR. Comprehensive treatment of ambulatory children with cerebral palsy: an outcome assessment. J Pediatr Orthop 2004;24:45-53.

15. Palisano R, Rosenbaum P, Walter S, Russell D, Wood E, Galuppi B. Development and reliability of a system to classify gross motor function in children with cerebral palsy. Dev Med Child Neurol 1997;39:214-23.

16. Palisano RJ, Rosenbaum P, Bartlett D, Livingston $\mathrm{MH}$. Content validity of the expanded and revised Gross Motor Function Classification System. Dev Med Child Neurol 2008;50:744-50.

17. Oeffinger DJ, Tylkowski CM, Rayens MK, Davis RF, Gorton GE 3rd, D'Astous J, et al. Gross Motor Function Classification System and outcome tools for assessing ambulatory cerebral palsy: a multicenter study. Dev Med Child Neurol 2004;46:311-9.

18. Paul SM, Siegel KL, Malley J, Jaeger RJ. Evaluating interventions to improve gait in cerebral palsy: a metaanalysis of spatiotemporal measures. Dev Med Child Neurol 2007;49:542-9.
19. Thomason P, Baker R, Dodd K, Taylor N, Selber P, Wolfe $\mathrm{R}$, et al. Single-event multilevel surgery in children with spastic diplegia: a pilot randomized controlled trial. J Bone Joint Surg Am 2011;93:451-60.

20. Abel MF, Damiano DL, Pannunzio M, Bush J. Muscletendon surgery in diplegic cerebral palsy: functional and mechanical changes. J Pediatr Orthop 1999;19:366-75.

21. Lee KM, Chung CY, Park MS, Lee SH, Choi IH, Cho TJ, et al. Level of improvement determined by PODCI is related to parental satisfaction after single-event multilevel surgery in children with cerebral palsy. J Pediatr Orthop 2010;30:396-402.

22. Blumetti FC, Wu JC, Bau KV, Martin B, Hobson SA, Axt $\mathrm{MW}$, et al. Orthopedic surgery and mobility goals for children with cerebral palsy GMFCS level IV: what are we setting out to achieve? J Child Orthop 2012;6:485-90.

23. Godwin EM, Spero CR, Nof L, Rosenthal RR, Echternach JL. The gross motor function classification system for cerebral palsy and single-event multilevel surgery: is there a relationship between level of function and intervention over time? J Pediatr Orthop 2009;29:910-5.

24. Wood L, Firth GB, Potterton J. Short-term outcomes of single event multilevel surgery for children with diplegia in a South African setting. SA Orthop J 2018;17:44-8.

25. Harvey A, Graham HK, Morris ME, Baker R, Wolfe R. The Functional Mobility Scale: ability to detect change following single event multilevel surgery. Dev Med Child Neurol 2007;49:603-7. 